\title{
An Urban Planning Sustainability Framework: Systems Approach to Blue Green Urban Design
}

Pepe Puchol-Salort ${ }^{\mathrm{a}}$, Jimmy O'Keeffe ${ }^{\mathrm{b}}$, Maarten van Reeuwijk $\mathrm{k}^{\mathrm{a}}$, Ana Mijic ${ }^{\mathrm{a}}$

${ }^{a}$ Department of Civil and Environmental Engineering, Imperial College London, Imperial College Rd, SW7 2BB, UK

${ }^{\mathrm{b}}$ Centre for Environmental Policy, Imperial College London, 16-18 Princes Gardens, London, SW7 1NE, UK

"Corresponding author: Pepe Puchol-Salort. Email: i.puchol-salort18@imperial.ac.uk. Address: Room 302, Skempton Building, Imperial College London, Imperial College Rd, SW7 2BB, UK

\section{ABSTRACT}

The climate emergency and population growth are challenging water security and sustainable urban design in cities worldwide. Sustainable urban development is crucial to minimise pressures on the natural environment and on existing urban infrastructure systems, including water, energy, and land. These pressures are particularly evident in London, which is considered highly vulnerable to water shortages and floods and where there has been a historical shortage of housing. However, the impacts of urban growth on environmental management and protection are complex and difficult to evaluate. In addition, there is a disconnection between the policy and decision-making processes as to what comprises a sustainable urban development project.

Here we present a systems-based Urban Planning Sustainability Framework (UPSUF) that integrates sustainability evaluation, design solutions and planning system process. One of the features of this master planning framework is the spatial representation of the urban development in a Geographical Information System to create an operational link between design solutions and evaluation metrics. UPSUF moves from an initial baseline scenario to a sustainable urban development design, incorporating the requirements of governance and regulatory bodies, as well as those of the end-users. It evaluates the impact on the built and the natural environments through the concept of urban ecosystem services, and makes the 
process for sustainable design more accurate and reliable. Ultimately, UPSUF has the potential to facilitate partnership and constructive dialogue between the public and the private sectors.

Keywords: Urban sustainability framework, Systems approach, Urban planning, Blue green urban design, Urban ecosystem services, Urban natural capital

\section{Introduction}

Human activities linked to urbanisation have significant impacts on the natural environmental. Currently, more than $50 \%$ of the world's population live in urban areas; a figure that will reach $66 \%$ by 2050 (United Nations, 2014). Globally, this has led to unsustainable development patterns as cities are forced to cope with a rapidly growing population and increasing societal requirements such as fresh water and sanitation, clean air, good transport links and new facilities (housing, education, recreation, etc.; Shao, 2020). In the UK, this level of growth will be particularly critical in London, where population is projected to increase by 70,000 people every year, reaching 10.8 million citizens in 2041 (Committee on Climate Change, 2019; GLA, 2019). This unprecedented urban growth and housing demand is putting pressure on the capital's land, housing, infrastructure and natural environment. London is also one of the most at-risk urban areas to climate change, facing water supply challenges (i.e. a rapidly increasing supply-demand gap), heat waves, flooding and air pollution (Environmental Agency, 2009; Clark et al., 2018; Ford et al., 2019; GLA, 2019). This is particularly evident in the water management field. Clark et al. (2018) suggested that one of the main priorities for the UK Government should be to protect their citizens from flooding and to reverse the decline of nature urgently. While the revised National Planning Policy Framework (NPPF) and 25-Year Environment Plan (25YEP) already provide some good ideas, more ambitious and specific targets are needed together with a strong and clear regulatory framework (Clark et al., 2018). While managing the effects of urban growth represents a significant challenge, it also provides an opportunity to rethink how we plan and design our urban spaces to support sustainability, both in terms of new urban development projects and in retrofitting existing urban spaces. 
An urban development project includes the design of built grey infrastructure (i.e. buildings and supporting civil infrastructure such as roads, pavements, etc.) along with associated green and blue space around it (generally nature-based solutions, which include vegetation, blue spaces, i.e. rivers and lakes, and other types of natural surfaces: Erell et al., 2015; Wu et al., 2019). While definitions of urban sustainability vary (see Oke and Stewart, 2012; Erell et al., 2015), overarching principles include offsetting increasing pressures on the natural environment or infrastructure systems, while providing the same opportunities that we currently have to future generations (Brundtland, 1987; Riera Pérez et al., 2018; Barbier, 2019). Blue green urban design integrates sustainable construction and sustainable urban form concepts in the design of buildings; and where possible, the use of Blue Green Infrastructure (BGI) in the open space areas (Kilbert, 2013; Bozovic et al., 2017; Davoudi and Sturzaker, 2017; Opoku, 2019). BGI is understood to be a strategically planned network of nature-based urban features that provide a wide range of Urban Ecosystem Services (UES; Brears, 2018; Mijic and Brown, 2019). Some examples of BGI are: street trees; permeable paving; engineered stormwater controls; blue and green roofs; green façades; parks and open spaces; ponds and waterways; urban gardens; etc. (Kabisch et al. 2017; Nesshöver et al., 2017; Keeler et al., 2019).

However, defining sustainable urban development indicators within an urban planning policy and decision-making context is difficult, both in research and in the professional practice fields. This is largely due to the complex interactions between many different types of systems in urban settings (Batty, 2008; Pandit et al., 2017; Boeing, 2018; Yeo and Lee, 2018). These include social, built and natural systems which intersect and interact in numerous complex ways that represent new urban pressures (land use change, air and soil contamination, green space reduction, etc.) and critical challenges (social equity, wellbeing, administrative cooperation, etc.; McPhearson et al., 2016). Developing whole-system understanding is central to: 1) integrating multiple aspects of sustainable development for blue green urban design (Oke and Stewart, 2012; Russo and Cirella, 2020); 2) evaluating and justifying design sustainability for multiple stakeholders (Pandit et al., 2017; Bide and Coleman, 2019); and, 3) 
utilising the multiple benefits provided by the natural environment through ecosystem services evaluation (Ossa-Moreno et al., 2017; Mijic and Brown, 2019). In the context of decisionmaking, investment in natural ecosystems versus traditional engineering solutions is underresearched and there is little evidence to prove their key role for urban sustainability (Nesshöver, 2017). Achieving urban sustainability, therefore, requires an appropriate methodology with shared evaluation metrics which links planning, ecological and engineering design perspectives within urban environments. These perspectives can be linked using a systems thinking approach, employed by engineers and researchers to develop quantitative models and new forms of integration to understand urban complexities (Whyte et al., 2020). There is a growing interest to develop sustainability evaluation frameworks at different urban scales (regional, city or district scales). Some examples include: the conceptual framework for water net-positive buildings from Joustra and Yeh (2014); the sustainability framework for trade-offs in ecosystem services from Cavender-Bares et al. (2015); the conceptual framework for urban water sustainability from Yang et al. (2016); the Nature-Based Solutions assessment framework from Raymond et al. (2017); or, the Urban Integrated Assessment Framework from Ford et al. (2019); among others. Mellino et al. (2014) combine the use of Geographical Information System (GIS) software with spatial planning evaluation. However, little evidence is available about fully integrated and systems thinking frameworks that integrate planning system process and align urban design solutions with the actions happening at the decisionmaking level. Bozovic et al. (2017) placed a strong emphasis on a highly structured preplanning phase as part of their Blue Green Systems approach; however, they did not specify in detail how to achieve this.

In this paper, we present an Urban Planning Sustainability Framework (UPSUF) to address these challenges; we combine evaluation methods with the UK planning process to facilitate a common understanding of the opportunities for sustainable urban design. The conceptual framework combines sustainability evaluation, GIS-supported design solutions and planning system process; enabling improved assessment and decision-making for a multi-stakeholder urban development projects. The sustainability evaluation is based on the UES assessment, 
which combines benefits provided from natural spaces within the urban boundaries (Tan et al., 2020). This is aligned with the concept of Natural Capital as a human-centred approach based on understanding nature's assets and their real value for human well-being (Barbier, 2019; Bright et al., 2019; Bateman and Mace, 2020). An important feature of UPSUF is the spatial representation of the urban development within a Geographical Information System (GIS) tool, linking the design solutions and its integrated evaluation toolkit in a more comprehensive way. Visualisation makes the process for sustainable design more effective and reliable, leading to better planning decisions (Mellino et al., 2014).

The paper is organised as follows: firstly, a general description of UPSUF is provided; followed by a detailed explanation of its three main components: a) Planning System Process, b) Sustainable Design Solutions and, c) Integrated Evaluation Toolkit. Secondly, the main case study area is presented, where the framework is conceptualised and tested. Thirdly, results comparing four urban design scenarios are presented and discussed. Finally, potential future work is presented, followed by the closing remarks.

\section{Methodology:}

\subsection{General description of UPSUF}

\subsubsection{A systems approach to urban planning}

To achieve sustainable urban design, it is necessary to look at a city holistically (Pandit et al., 2017); building an understanding of many interdependencies and operational risks inherent within urban built, natural and social systems. Viewing a city as a 'system of systems' (Kotov, 1999; Little et al., 2019) presents a significant challenge, but one which can be addressed through systems thinking (see Keating et al., 2003; Williams et al., 2017). In this work we apply systems thinking as an engineering approach which provides a framework for integrated analysis of land and building systems that require stakeholders' coordination, and can help decision-makers achieve objectives of the system as a whole (Pandit et al., 2017; Whyte et al., 2020). Sustainable urban development requires a balance of several objectives and opportunities such as affordable housing, good transport links, clean air and water, biodiversity 
or community services (education, recreation, etc.); although these are sometimes in disagreement and present serious challenges (Keeler et al., 2019). Additionally, a systems approach is the best way to reliably compare Blue-Green versus grey approaches to address urban sustainability challenges, evidencing their real value from a long-term perspective (Keeler et al., 2019). For all these reasons, systems thinking lies at the core of UPSUF, which is defined by two key elements: 1) improved urban development design and evaluation process through integration of the built and natural system components using the concept of UES; and, 2) improved system understanding and decision-making through integration of multiple stakeholder perspectives in the planning and co-development process.

\subsubsection{The Urban Planning Sustainability Framework (UPSUF)}

The UPSUF (Figure 1) is based on the UK's planning system and addresses the ambition of city councils to grant more planning applications to urban development projects that are considered 'sustainable' (HM Government, 2015; Clark et al., 2019). Hence, this framework is primarily aimed at two stakeholder groups: 1) those involved in development and construction (housing developers, urban planners, and designers, i.e. engineers, architects, etc.); and, 2) those involved in planning and use (Local Planning Authorities (LPAs) or City Planners, and residents). This is in addition to statutory consultees which include water companies, as part of the private sector, and the Lead Local Flooding Authorities (LLFAs), as part of the public sector. While all stakeholders have specific objectives and look at urban planning through a different lens, all share a common challenge: an incapacity to collectively determine whether an urban development project can be considered 'sustainable' or not (HM Government, 2018). 


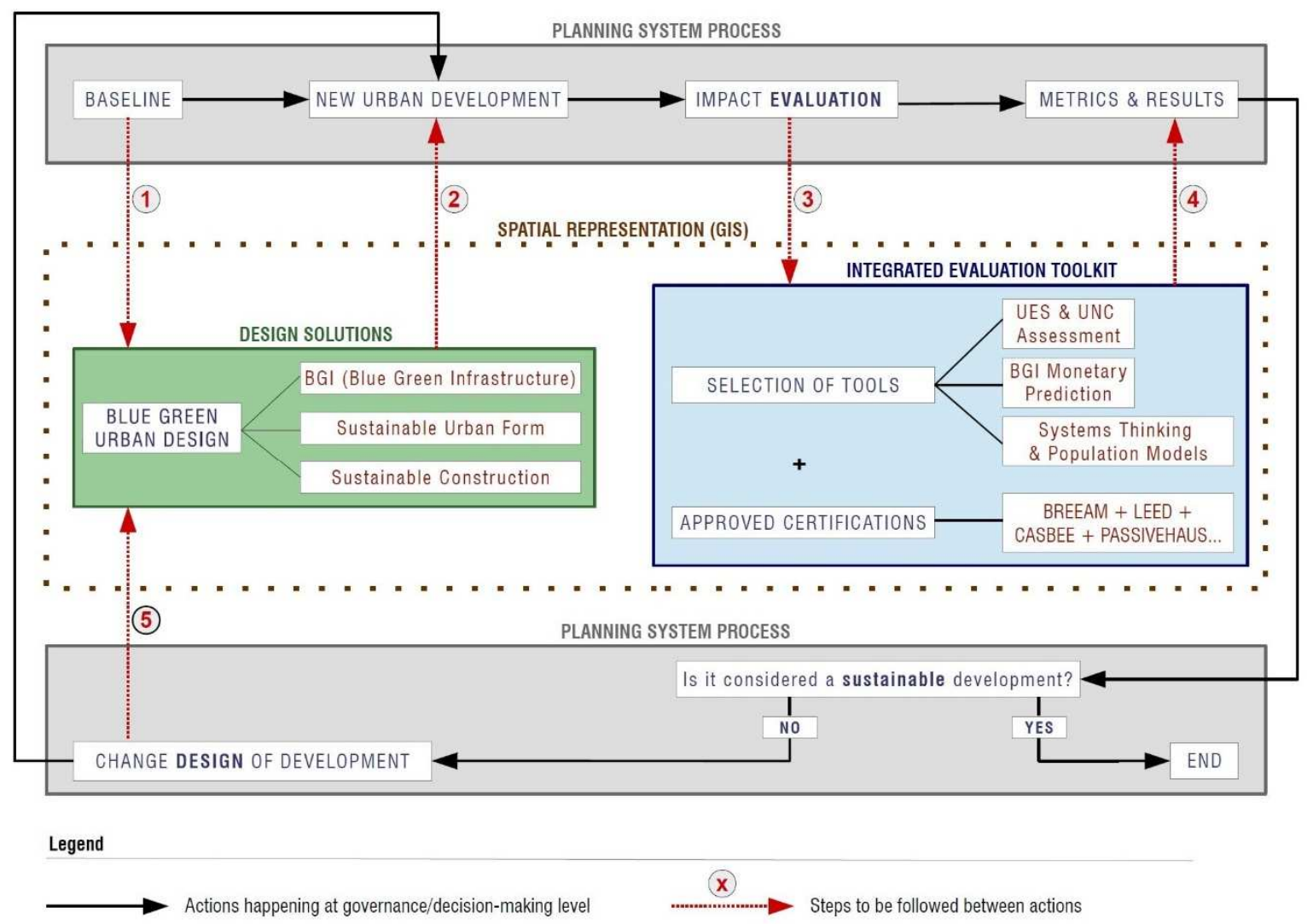

Fig. 1: General diagram of the Urban Planning Sustainability Framework (UPSUF). Its three components are: 1) Planning System Process (in grey); 2) Design Solutions (in green); and, 3) Integrated Evaluation Toolkit (in blue). The governance and decision-making actions are represented by black arrows, while the five steps indicated by the framework are represented by numbered red arrows.

UPSUF is comprised of five steps (red arrows in Figure 1) based on the UK's planning system's process (black arrows in Figure 1). These steps help guide the user from an existing urban development baseline to a new validated and sustainable development project. These five steps operate across three framework components: 1) Planning System Process; 2) Design Solutions; and, 3) Integrated Evaluation Toolkit (grey, green, and blue clusters in Figure 1, respectively). The application of UPSUF is an iterative process, linking the design solutions with an evolving integrated evaluation toolkit, which are all spatially represented in a GIS tool to achieve more reliable and accurate results. This process is designed to reflect current planning phases, mirroring the different design-cycle actions that an urban 
development project undergoes at governance and decision-making level until the planning application is granted.

\subsubsection{UPSUF application}

The framework's operation consists of five distinct steps (see Figure 1). Establishing the baseline conditions of the development site, or the pre-development scenario, forms an essential first step of any new urban development design. The type of information required is dependant on the type of redevelopment but may involve surveys of site ecology, current infrastructure, land use and hydrology (Jabareen, 2006). As previously explained, blue-green urban design includes the combination of Blue Green Infrastructure (BGI) with sustainable urban form and sustainable construction principles (Kilbert, 2013; Erell et al., 2015; Oke et al., 2017). Once these new integrated design solutions are combined and applied to the existing baseline, a new urban development is obtained in step 2 .

The third step of the framework is comprised of an integrated evaluation process to assess if the proposed development is considered sustainable under planning guidelines. The UPSUF has capacity to integrate a series of tools, including NCPT (Natural Capital Planning Tool; Hölzinger et al., 2019) or B£ST (Benefits Estimation Tool; Ciria, 2019), among others. These tools combine an UES assessment method with BGI cost-benefit evaluation; however, UPSUF is designed as an adaptable and extensible system allowing continual improvement during its application on real case studies, where approved certifications such as BREEAM Communities (Building Research Establishment Environmental Assessment Method; BRE Global, 2017), LEED-ND (Leadership in Energy and Environmental Design; USGBC, 2012), CASBEE-UD (Comprehensive Assessment System for Built Environment Efficiency; IBEC, 2014) and PASSIVEHAUS (Passive House Institute, 2020) could be added. In step 4, the evaluation process will combine UPSUF's visual representation of the urban development using GIS with a series of sustainability indicators.

Finally, the fifth step of the framework application involves a comparison of the outputs with established sustainability metrics. If results indicate that the proposed development is 
sustainable, this may be the final stage of the design process. However, if the metrics suggest the proposed development is unsustainable, or not sustainable enough, the process continues by modifying the design solution based on the indicators feedback (back to step 2). The iterative process of the UPSUF application provides a standardised sequence which take the user from an initial baseline scenario to a sustainable urban development plan, incorporating the requirements of governance and regulatory bodies, as well as those of the end-users predominantly the residents. This approach also facilitates the exploration and quantitative evaluation of scenarios and testing different design options, all of which can then be compared to the baseline and the sustainability metrics.

\subsection{Planning System Process}

The planning system process is the first component of the UPSUF. Early engagement with the planning system and local stakeholders is crucial to delivering sustainable urban development (UNISDR, 2017; Clark et al., 2019). In some cases, engagement may take place prior to land purchase; allowing developers to assess the costs (profitability) and viability of the development project. It also provides an opportunity to demonstrate the sustainability credentials of the development proposal to Local Planning Authorities. Typically, there are a number of urban stakeholder groups involved in the planning application process. These include private and public sector actors, although there is often overlap between the two groups, for example the same stakeholder (e.g. developers) might be either in the private or the public sector. A graphical representation of the UK's planning process and the five stages explained below is shown in Figure 2 . 


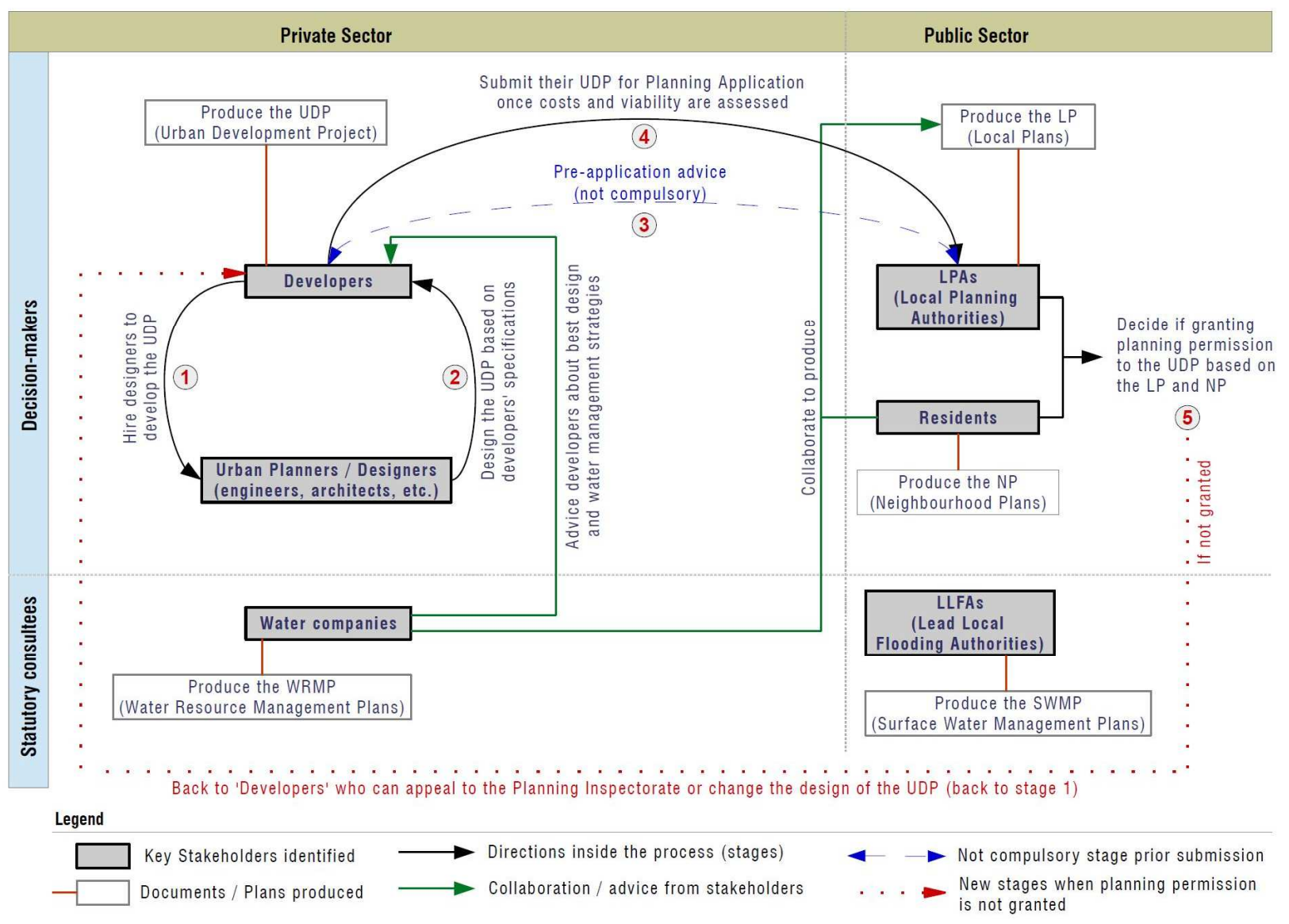

Note: In some cases, the 'Developers' can be the LAs (Local Authorities) as most councils in the UK have land to develop. Although in this context the 'Developers' figure will be in the Public Sector too, it should be a differentiation of functions between LAs and LPAs to ensure transparency.

Fig. 2: Overview of the urban planning application process in the UK's planning context. Urban planning stakeholders are divided between private and public sectors; and between two decision groups: decision-makers and statutory consultees. The compulsory stages for planning application are represented with black arrows and red numbering; while pre-application advice is not compulsory and it is represented with blue dotted double arrowed line. In case planning application is not granted, developers can appeal the decision or move back to stage 1 (red dotted arrow).

Stakeholders can be divided into 'decision-makers' (those who are responsible for decisions) and 'statutory consultees' (who advise other stakeholders and collaborate to produce Local Plans). Decision-makers may include developers, urban planners and designers, Local Planning Authorities (LPAs) and neighbours; while statutory consultees include water companies, and Lead Local Flooding Authorities (LLFAs).

Developers typically produce and submit urban development projects using the expertise of designers and urban planners, as well as a team of engineers and architects specialised in 
urban systems design and infrastructure (Clark et al., 2018). Development plans (stage 1) are based on developers' specifications while also soliciting advice from statutory consultees such as water companies, who produce the Water Resource Management Plans, (WRMP; Bide and Coleman, 2019). Their advice is generally focused on best water management strategies and viability for $\mathrm{BGI}$.

Following draft production of the urban development project (stage 2), developers have the option to obtain pre-application advice from LPAs (stage 3). While this stage is not compulsory, it provides a cost-effective way of assessing the viability of the development prior to the planning application submission (HM Government, 2019).

Once all relevant sustainability and economic variables have been assessed and addressed by developers, the planning application can be submitted to the LPAs (stage 4). LPAs produce the Local Plans incorporating advice, where necessary from statutory consultees such as water companies, who produce the WRMP, and from residents, who contribute to the Neighbourhood Plans (HM Government, 2015, 2019).

Developers and urban planners can then move to more detailed design and building specifications if planning is granted (stage 5). If planning permission is not granted, developers are able to appeal to the Planning Inspectorate or change the design of the urban development project, effectively returning to stage 1 . A clear alignment between the UPSUF's actions (black arrows in Figure 1) and the planning system process (Figure 2) is evident at this stage. Many councils in the UK own strategically important land, which they may wish to develop, for example, as affordable housing or publicly accessible space (Bide and Coleman, 2019). To ensure full transparency under such circumstances there should be a differentiation of functions between Local Authorities and Local Planning Authorities, where LPAs in conjunction with residents decide if planning should be granted.

It is not uncommon that sustainability becomes a secondary goal to project viability and profitability for developers (Clark et al., 2018; HM Government, 2019; Bide and Coleman, 2019). The main aim of UPSUF is to express the real benefits of sustainable design solutions using evaluation tools and metrics. Therefore, both private and public sectors can benefit from 
UPSUF guidance at the early stages of the design process, both in terms of the proposal viability and provision of a platform for the co-production of potential solutions.

\subsection{Sustainable Design Solutions}

The second component of the UPSUF involves integrated principles for sustainable urban design solutions. These are applied to the initial pre-development case study and involve a mixture of built grey and Blue Green infrastructures. In the long term, the benefits provided by BGI can outweigh those of traditional grey infrastructure (Bozovic et al., 2017), but achieving urban sustainability requires facilitating the flow of UES while including sufficient grey infrastructure to achieve the goals of the development in terms of housing, transport, water infrastructure, etc. (Kapetas and Fenner, 2020; Newton and Rogers, 2020). As a result, it is necessary to determine what the optimal combination of BGI vs grey interventions should be. We explore this link by integrating BGI with urban form and construction concepts. From sustainable urban form concept, we specifically focus on: i) building dimensions and spacing, avoiding overly compact or sprawled urbanisation; ii) building density and use, supporting mixed-use buildings and a healthy number of habitants $/ \mathrm{m}^{2}$ of the building; iii) surface properties, avoiding impervious and paved areas; and, iv) the amount of green space around the buildings, placing as much green space as possible in the open spaces. While from the sustainable construction perspective, we include the use of local and natural materials, and an efficient use of resources during construction and life cycle of the building (water, energy, etc.). Table A.1 in Appendix A compares sustainable with more traditional design solutions supported by the UPSUF's blue green urban design solutions. Depending on the selected combination of solutions, a different number of UES will be provided. A comparison based on several sources of literature (Keeler et al., 2019; Bozovic et al., 2019) guided the selections of ten UES to be included in UPSUF evaluation (Table A.2 in Appendix A): air quality; Urban Heat Island effect mitigation; water quality; water supply; stormwater management; recreation and well-being; urban agriculture; biodiversity; aesthetics; and, resources efficiency. 
Blue green urban design solutions are generally assessed individually and a holistic approach that studies the UES provided by integrated design solutions is still lacking (Carmona et al., 2010). Hence, one of the innovations of UPSUF is the ability to quantify the impact of a combination of blue-green urban design solutions, increasing the number of UES provided. The UES provided by combinations of blue-green urban design solutions are described in Table 1 (e.g. street trees combined with sustainable urban form and sustainable construction provide seven UES, that are: 1) aesthetics, 2) UHI mitigation, 3) food mitigation and stormwater management, 4) urban air quality, 5) recreation and well-being, 6) resources efficiency and, 7) resources efficiency). Those UES will be crucial to offset the negative impacts of the new urban development in the form of housing, pollution, urban heat island effect or climate change, among others (Mijic and Brown, 2019).

Before moving to the evaluation stage, a series of design scenarios need to be developed. The comparison between these design scenarios forms an essential part of UES assessment (Mace et al., 2011); while it does not try to predict the future, it helps to recognise a range of future possibilities under different assumptions. This aligns with the UPSUF's approach because the framework has the capacity to explore different potential urban development options which are then compared to the existing baseline's conditions. Outputs can highlight potential options where urban development projects can more appropriately fit existing or future sustainability policies. 
Table 1: UES provided by the combination of the UPSUF blue green urban design solutions. BGI solutions are combined with sustainable urban form and sustainable construction principles.

\begin{tabular}{|c|c|c|c|c|c|c|c|c|}
\hline \multirow[b]{3}{*}{ Area } & & \multicolumn{6}{|c|}{ BUILDINGS } & \\
\hline & & \multicolumn{4}{|c|}{ Sustainable Urban Form } & \multicolumn{2}{|c|}{ Sustainable Construction } & \\
\hline & Design solution & $\begin{array}{l}\text { Building dimensions and } \\
\text { spacing (compactness) }\end{array}$ & Building density and use & Surface properties (cover) & $\begin{array}{l}\text { Amount of green space around } \\
\text { buildings }\end{array}$ & $\begin{array}{l}\text { Use of sustainable materials } \\
\text { (tabric) }\end{array}$ & $\begin{array}{l}\text { Efficient use of resources during construction and } \\
\text { life-time of the building (water, energy, etc.) }\end{array}$ & TOTAL N. of UES \\
\hline \multirow{16}{*}{ 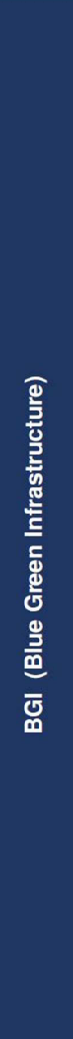 } & \multirow{2}{*}{ Street trees } & \multirow{2}{*}{ Aesthetics } & \multirow{2}{*}{ UHI mitigation } & \multirow{2}{*}{$\begin{array}{c}\text { Flood mitigation and } \\
\text { stormwater management }\end{array}$} & Urban Air quality & & Resources efficiency & \multirow{2}{*}{7} \\
\hline & & & & & Recreation and well-being & & Urban water supply & \\
\hline & Permeable paving & & & $\begin{array}{l}\text { Flood mitigation and } \\
\text { stormwater management }\end{array}$ & & Resources efficiency & Urban water supply & 3 \\
\hline & \multirow{2}{*}{$\begin{array}{l}\text { Engineered stormwater controls (bioswales, rain } \\
\text { gardens and retention ponds) }\end{array}$} & Urban Water quality & & $\begin{array}{l}\text { Flood mitigation and } \\
\text { stormwater management }\end{array}$ & Urban Water quality & & \multirow{2}{*}{ Resources efficiency } & \multirow{2}{*}{7} \\
\hline & & UHI mitigation & & Aesthetics & Urban water supply & & & \\
\hline & \multirow{2}{*}{ (Blue) Green roofs } & \multirow{2}{*}{ Aesthetics } & \multirow{2}{*}{ UHI mitigation } & \multirow{2}{*}{$\begin{array}{c}\text { Flood mitigation and } \\
\text { stormwater management }\end{array}$} & Biodiversity & \multirow{2}{*}{ Resources efficiency } & & \multirow{2}{*}{6} \\
\hline & & & & & Urban Air quality & & & \\
\hline & \multirow[b]{2}{*}{ Green façades/walls } & \multirow[b]{2}{*}{ Aesthetics } & \multirow[b]{2}{*}{ UHI mitigation } & & Biodiversity & & \multirow[b]{2}{*}{ Resources efficiency } & \multirow[b]{2}{*}{5} \\
\hline & & & & & Urban Air quality & & & \\
\hline & \multirow{3}{*}{ Parks and open spaces } & \multirow{3}{*}{ Aesthetics } & UHI mitigation & \multirow{2}{*}{$\begin{array}{l}\text { Flood mitigation and } \\
\text { stormwater management }\end{array}$} & Biodiversity & & Resources efficiency & \multirow{3}{*}{10} \\
\hline & & & \multirow{2}{*}{ Urban Water quality } & & Urban Air quality & & \multirow{2}{*}{ Urban water supply } & \\
\hline & & & & Urban agriculture & Recreation and well-being & & & \\
\hline & Rainwater harvesting systems & & & $\begin{array}{l}\text { Flood mitigation and } \\
\text { stormwater management }\end{array}$ & & Resources efficiency & Uiban water supply & 3 \\
\hline & \multirow{2}{*}{ Ponds, waterways and wetlands } & \multirow{2}{*}{ Aesthetics } & & \multirow{2}{*}{$\begin{array}{l}\text { Flood mitigation and } \\
\text { stormwater management }\end{array}$} & Recreation and well-being & & Resources efficiency & \multirow{2}{*}{6} \\
\hline & & & & & Biodiversity & & Urban water supply & \\
\hline & Urban gardens & Recreation and well-being & Urban agriculture & & Biodiversity & & Resources efficiency & 4 \\
\hline
\end{tabular}




\subsection{Integrated Evaluation Toolkit}

The third component of the UPSUF is an integrated evaluation toolkit - a flexible and evolving cluster that has the capacity to select different evaluation tools and models depending on the specific case study. The various combinations of blue-green urban design solutions (Table 1) will be analysed and assessed using computational tools within the UPSUF's integrated evaluation toolkit. There are a number of different tools which can be used for UES assessment. Some of the most commonly used are: B£ST (Benefits Estimation Tool; Ciria, 2019); InVest (Integrated Valuation of Ecosystem Services and Trade-offs; Sharp et al., 2018); and, NCPT (Natural Capital Planning Tool; Hölzinger et al., 2019). Among them, NCPT is one of the most commonly used in the urban planning context in the UK. This tool is primarily aimed at the urban development scale and provides numerical (but qualitative) scores for several UES, covering most of the ten UES classified in UPSUF (Table A.2, Appendix A). The only two UES missing in the NCPT compared to UPSUF are: a) urban water supply, and b) resources efficiency. However, NCPT lacks a graphical representation of land use, reducing the capacity of the evaluation to generate useful evidence or fully engage with stakeholders. In order to support planning policies that describe the spatial and temporal interactions of an urban development project together with its socio-economic factors, new analytical tools are required (Ford et al., 2018, 2019). UPSUF attempts to upgrade NCPT's functionality through the spatial representation of both pre- and post-development land-use areas of the urban development site using GIS software. This improves the accuracy of results and allows more flexibility in terms of considering other architectural design parameters, such as orientation or urban form of buildings, which directly affect the environmental and thermal performance of the urban development (Jabareen, 2006; Erell et al. 2015; Ahmadian et al., 2019). The framework currently uses QGIS (Cavallini et al., 2019) for this purpose as it is a free and opensource tool, and can be easily shared with all relevant stakeholders. While quantification of benefits provided by sustainable design solutions can be achieved through various metrics, the inclusion of computational tools with the capacity for a spatial representation has the potential to provide significant increased benefit (Mijic and Brown, 2019). Including GIS 
capabilities in UPSUF improves its capacity to demonstrate the implications of change, generating evidence on the benefits of the proposed urban developments to stakeholders and delivering solutions that achieve maximum sustainability values.

\section{Case Study: Thamesmead Waterfront Development Plan}

Thamesmead is a 750-ha area in Southeast London currently undergoing a large regeneration programme that will last for the next 30 years. Located between two London boroughs (Figure 3): Greenwich (Thamesmead Moorings) and Bexley (Thamesmead East), the area contains a significant number of social housing, originally built by the now-disbanded Greater London Council (GLC) as part of their 1967 Masterplan (Cherry and Pevsner, 1964). Currently Thamesmead is home to over 45,000 people in approximately 16,000 households, 5,200 of which are owned by the Peabody Housing Association (Ford and Baikie, 2016). Peabody also owns a significant portion of currently unused land, accounting for $65 \%$ of the Thamesmead area (Askew, 2018) of which approximately 150 ha are blue or green-space. This includes 32 ha of water comprising five lakes and $7 \mathrm{~km}$ of canals, five neighbourhood parks and 14 Sites of Nature Conservation Interest (SNCl). The total estimated Natural Capital potential value provided by Thamesmead’s blue and green-space is estimated to be at least £306 million or $£ 257$ per person per year (Askew, 2018; Vivid Economics, 2018). Despite this, most of the blue and green space remains underutilised with significant portions of the area currently inaccessible.

Current plans involve developing the area to accommodate significant increase in population: it is expected that by 2050 more than 100,000 people will call Thamesmead their home. This will involve improving its environmental and community qualities, turning Thamesmead into a centre of culture, arts and heritage. 


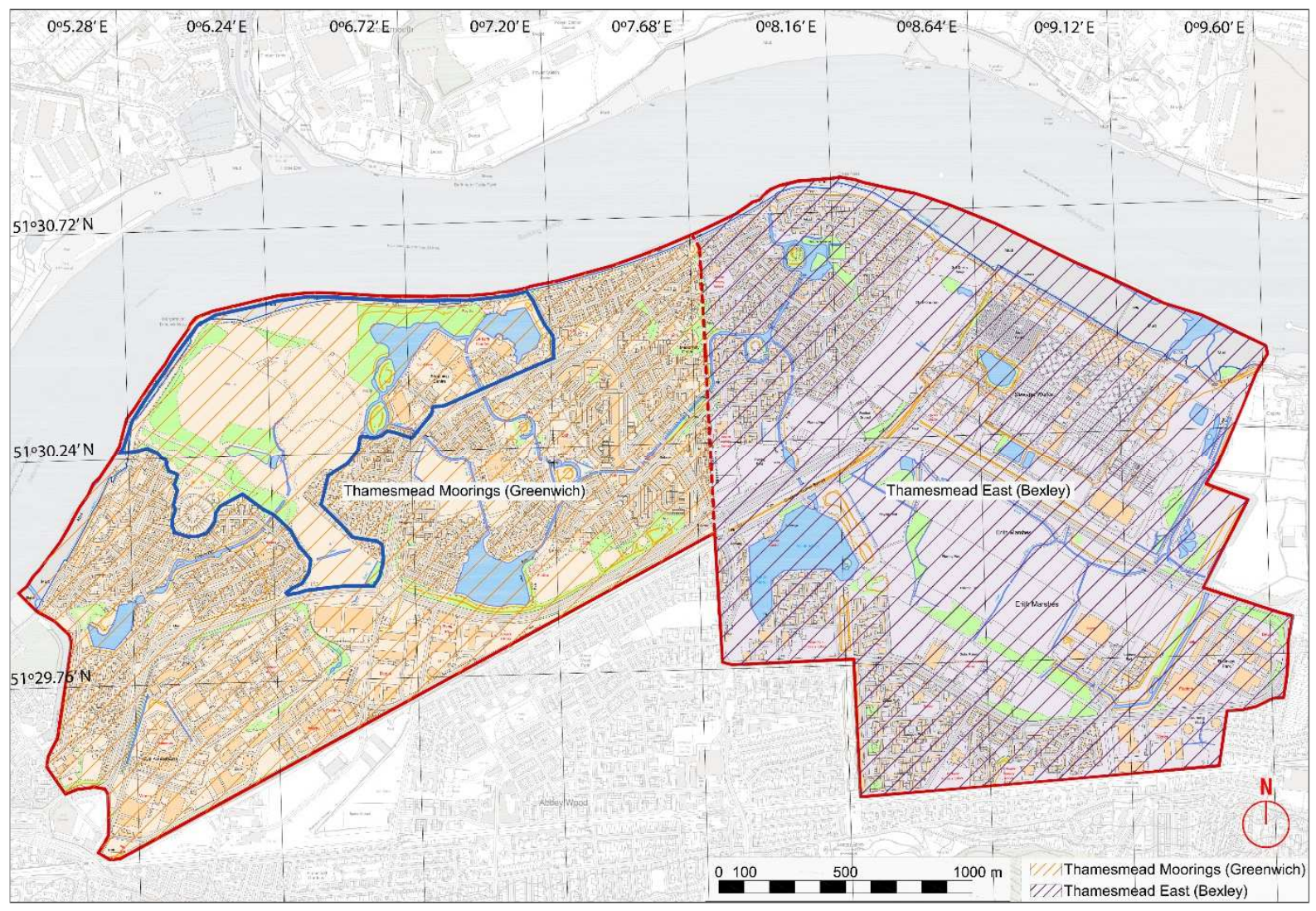

Fig. 3: Thamesmead's boundaries map inside the two boroughs: Greenwich and Bexley. Also, the Thamesmead Waterfront Development Plan area is circled by the blue line.

The Thamesmead Waterfront Development Plan (circled in blue in Figure 3) forms one of the most important aspects of this new development. The scheme will include more than 11,500 new homes within a 100-ha site, utilising almost $3 \mathrm{~km}$ of undeveloped river waterfront. Almost 80 ha of these 100 ha are brown, blue and green space managed solely by Peabody (Royal Borough of Greenwich, 2014), most of which is currently inaccessible. This generates a unique development opportunity to provide a diverse range of UES. This £8bn new urban development will be one of the largest projects of its type in Europe and will be based around a range of new transport connections, including a new DLR station connected to the Elizabeth Line (Crossrail) in Strafford and Forest Gate (GLA, 2018). 


\section{Results}

\subsection{Sustainable Urban Design Scenarios}

Thamesmead Waterfront Development Plan (TMWDP) will be used to evaluate the sustainability of design solutions for new urban developments. As part of UPSUF's integrated evaluation toolkit, Urban Natural Capital (UNC) and UES accounting will be a starting point to understand the environmental impact created by new housing developments.

We develop four urban design scenarios for TMWDP in order to compare different levels of environmental impact. However, before presenting these four urban development design scenarios, it is necessary to understand the pre-development land-use map, which will act as the initial baseline. This is represented based on research data previously collected and supplemented by OpenStreetMap and Google satellite maps.

Approximately $50 \%$ of the development site is currently developable brownfield land and hazardous-waste land-fill (Figure 4). Hazardous landfill cannot be used for building, but it has other potential uses, including a nature reserve. Under current planning conditions from the Royal Borough of Greenwich, blue space (lakes and canals), part of the amenity grassland and the protected wetland inside TMWDP must be preserved as Sites of Nature Conservation Importance $(\mathrm{SNCl})$. With the exception of the water-pump station, all existing buildings, predominantly supermarkets, department stores or leisure centres, will be removed and redesigned in all four design options. Paved areas (including car parks, and play areas) will 
be also redesigned, with the exception of the Thames path pedestrian and cycling trail, which is also protected by Greenwich planning policies.

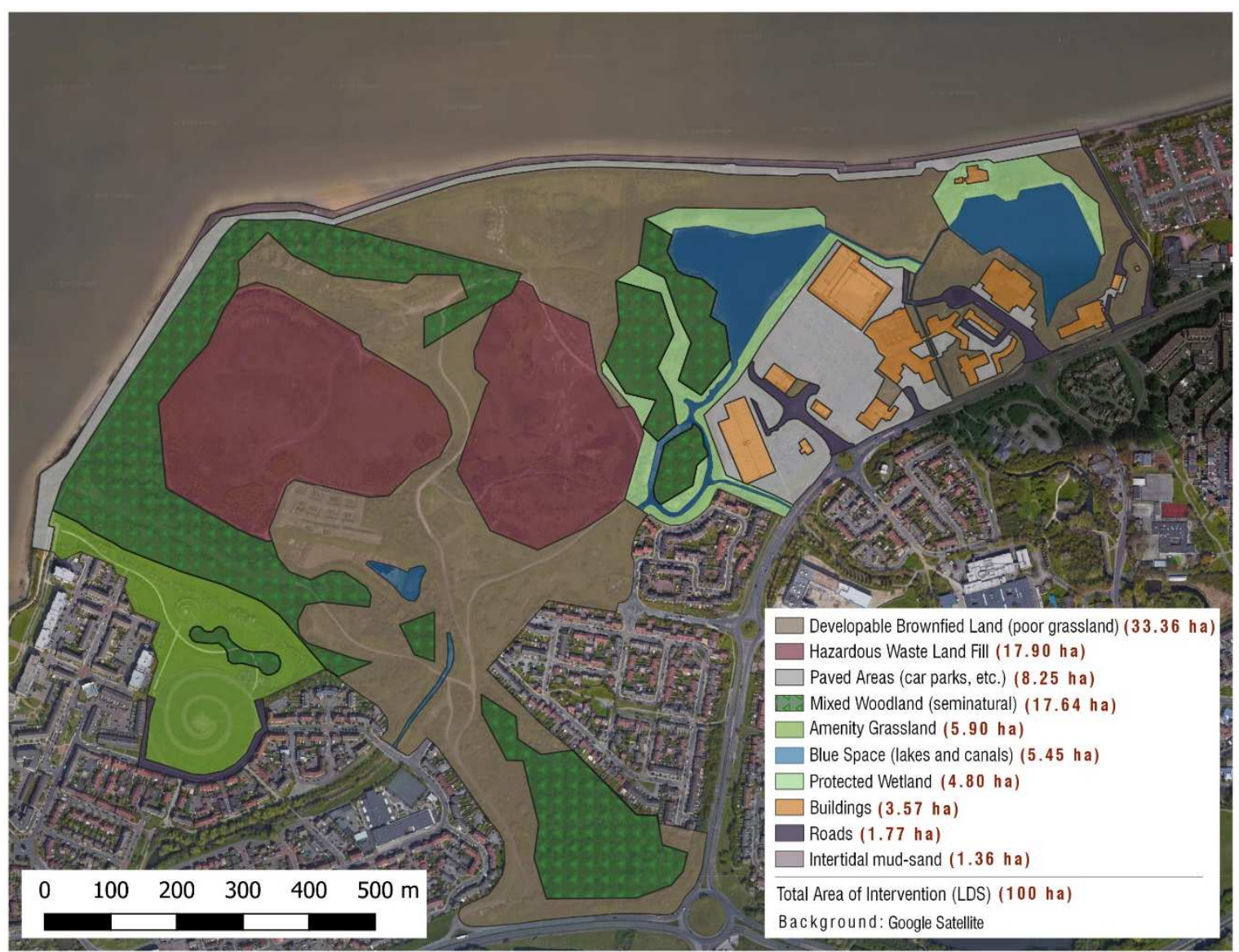

Fig. 4: Pre-development land-use map or 'baseline' for Thamesmead Waterfront Development Plan (TMWDP).

Based on the aforementioned constraints, a realistic but unfavourable scenario is developed (see Scenario 1 in Figure 5), which represents traditional building approaches: relying heavily on grey infrastructure and building solutions with minimal consideration of sustainable urban form (e.g. appropriate building orientation or green roofs; see Table 1). The built-up areas with different types of densities (high, medium and low) are built with traditional ways of construction. As aforementioned, blue space, protected wetland and intertidal mud-sand are preserved and have not changed. Other land-uses, such as mixed woodland and amenity grassland, have been diminished in some parts and then augmented elsewhere, especially where there is hazardous waste land fill at the moment. 
Scenario 2 represents the same number of built-up hectares of Scenario 1, but instead of being high-, medium-, or low-density built-up areas; those are exchanged for 'buildings covered with green roofs' or 'buildings with green walls' land uses (see Scenario 2 map in Figure 5). These two land uses are the only sustainable building options given by the NCPT. This is therefore seen as an important limitation of the tool. In the same way, the previous 'roads' have been replaced by 'local green roads'; while 'paved areas (car parks, etc.)' are transformed into 'gardens' (including the Thames path). NCPT does not give specific options for some of the BGI land uses in Table 1, such as permeable paving or engineered stormwater controls, which constitutes another important limitation of the tool.

Scenario 3 is based on a completely new urban layout design (Figure 5). In this case, more green, blue and recreation spaces are arranged around the built-up areas to increase the UES received. This scenario is based on compact densities and BGI around them, which is regarded to be a more sustainable option for future cities than low-density layouts (Ahmadian et al., 2019). Additionally: i) most existing woodland is preserved; ii) more woodland and pond areas are added inside the parkland; iii) gardens (which represent BGI) are placed around most of the building blocks; iv) blue space is considerably increased with new lakes and a new canal network.

Finally, Scenario 4 has a similar ethos to Scenario 3, but represents a more sensible option that preserves most of the existing natural environment, especially mixed woodland area, and leaves more space for BGI, represented as 'gardens' (see Figure 5). Additionally, buildings facing the river are envisioned as tall buildings with green roofs, while buildings with green walls are placed inland and pictured as medium-density buildings of between five and six floors tall. 


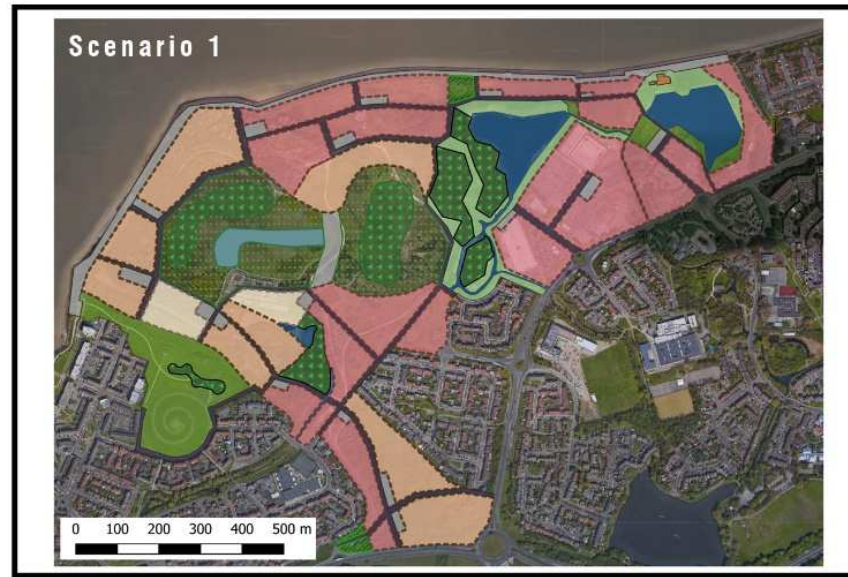

Built-up Area- High Density (28.75 ha)

Built-up Area- Medium Density (15.88 ha)

Built-up Area- Low Density (2.44 ha)

UIJ Gardens (0.64 ha)

.... Mixed Parkland - Scattered Trees (10.36 ha)

Pond $(1.26 \mathrm{ha})$

Mixed Woodland (seminatural) $(9.00 \mathrm{ha})$

Paved Areas (car parks, etc.) (5.85 ha)

Amenity Grassland (6.90 ha)

Blue space (lakes and canals) (5.45 ha)

Buildings (existing) $(0.08 \mathrm{ha})$

Protected Wetland (4.80 ha)

Roads (7.25 ha)

Intertidal mud-sand (1.36 ha)

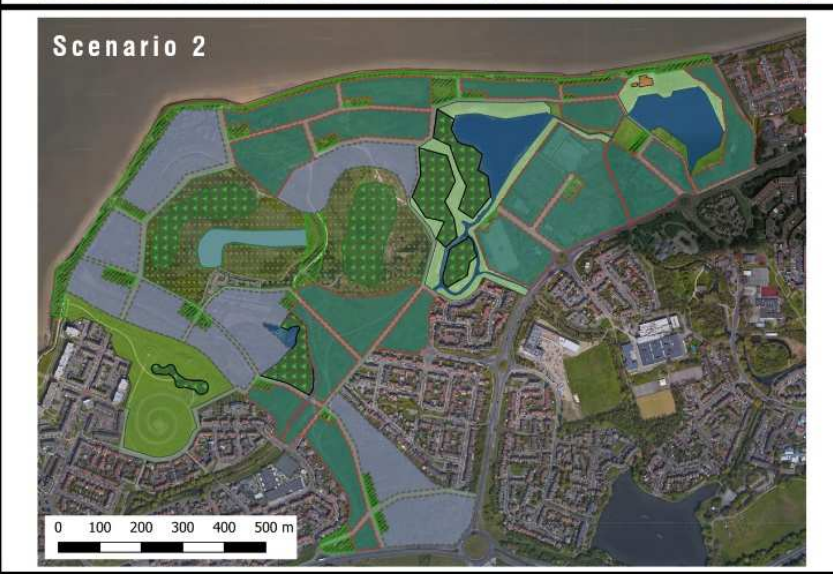

Buildins with green roofs (28.75 ha)

Buildings with green walls (18.32 ha)

Gardens (6.47 ha)

… Mixed Parkland - Scattered Trees (10.36 ha)

Pond (1.26 ha)

Ead Mixed Woodland (seminatural) ( 9.00 ha)

$\square$ Amenity Grassland (6.90 ha)

Blue space (lakes and canals) ( $5.45 \mathrm{ha}$ )

$\square$ Buildings (existing) (0.08 ha)

Protected Wetland (4.80 ha)

Local Green Roads (7.25 ha)

$\square$ Intertidal mud-sand ( 1.36 ha)

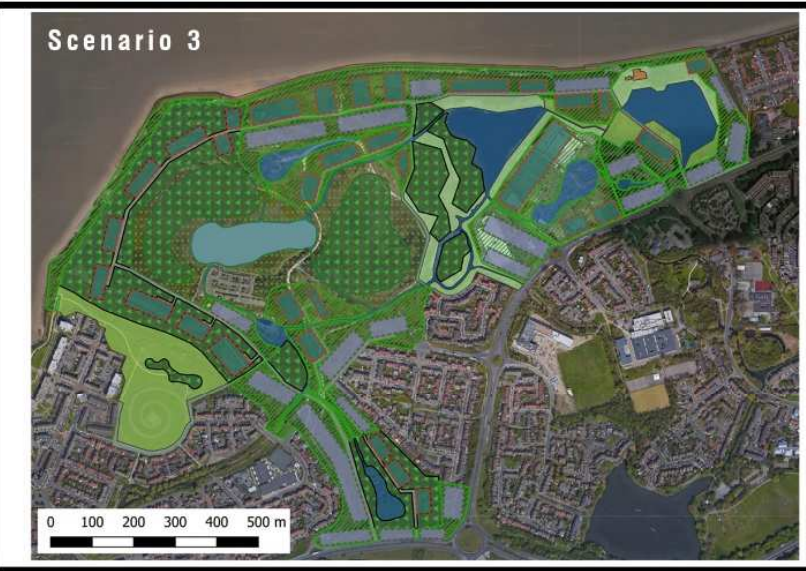

Buildins with green roofs (10.02 ha)

Buildings with green walls ( 8.68 ha)

VIA Gardens (21.39 ha)

... Mixed Parkland - Scattered Trees ( 8.43 ha)

$\square$ Pond (2.45 ha)

[ad Mixed Woodland (seminatural) (21.65 ha)

$\square$ Amenity Grassland (7.04 ha)

Blue space (lakes and canals) (9.54 ha)

$\square$ Buildings (existing) ( $0.08 \mathrm{ha})$

$\square$ Protected Wetland (4.80 ha)

Local Green Roads (4.56 ha)

$\square$ Intertidal mud-sand (1.36 ha)

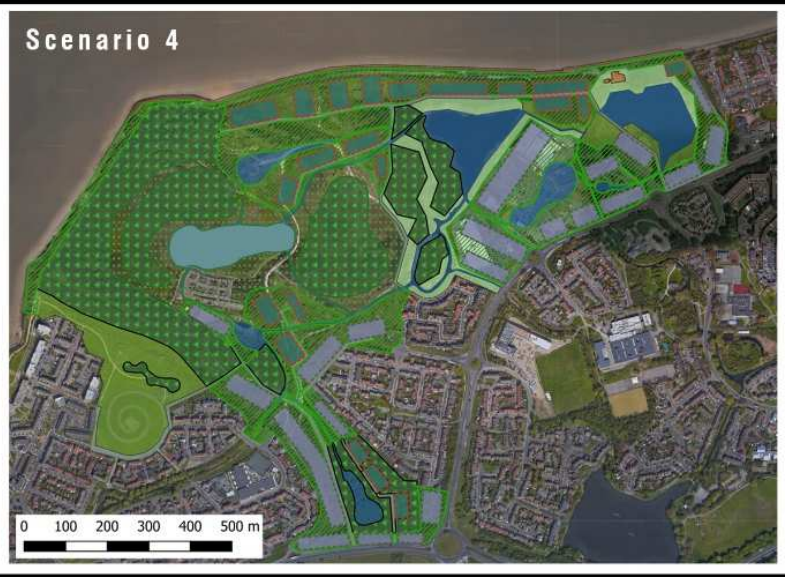

Buildins with green roofs ( $5.73 \mathrm{ha}$ )

Buld Buildings with green walls ( 8.82 ha)

Mardens (22.67 ha)

... Mixed Parkland - Scattered Trees ( 8.43 ha)

$\square$ Pond (2.45 ha)

Daxed Woodland (seminatural) (25.42 ha)

$\square$ Amenity Grassland (7.04 ha)

Blue space (lakes and canals) ( $9.54 \mathrm{ha}$ )

$\square$ Buildings (existing) ( $0.08 \mathrm{ha}$ )

$\square$ Protected Wetland (4.80 ha)

Local Green Roads (3.66 ha)

$\square$ Intertidal mud-sand (1.36 ha)

Fig. 5: Four post-development land-use scenario maps for Thamesmead Waterfront Development Plan (TMWDP) with land-use legends close to them. 


\subsection{Impact Evaluation Results}

In this section the numerical results obtained from the four spatially represented urban design scenarios are discussed and compared. These results are in the form of positive or negative scores for each UES analysed, which are summarised in Table 2.

Table 2: Ecosystem Services and Natural Capital Net-Gains scores obtained from the Natural Capital Planning Tool (NCPT) for the Thamesmead Waterfront Development Plan (TMWDP) in the four urban design scenarios studied.

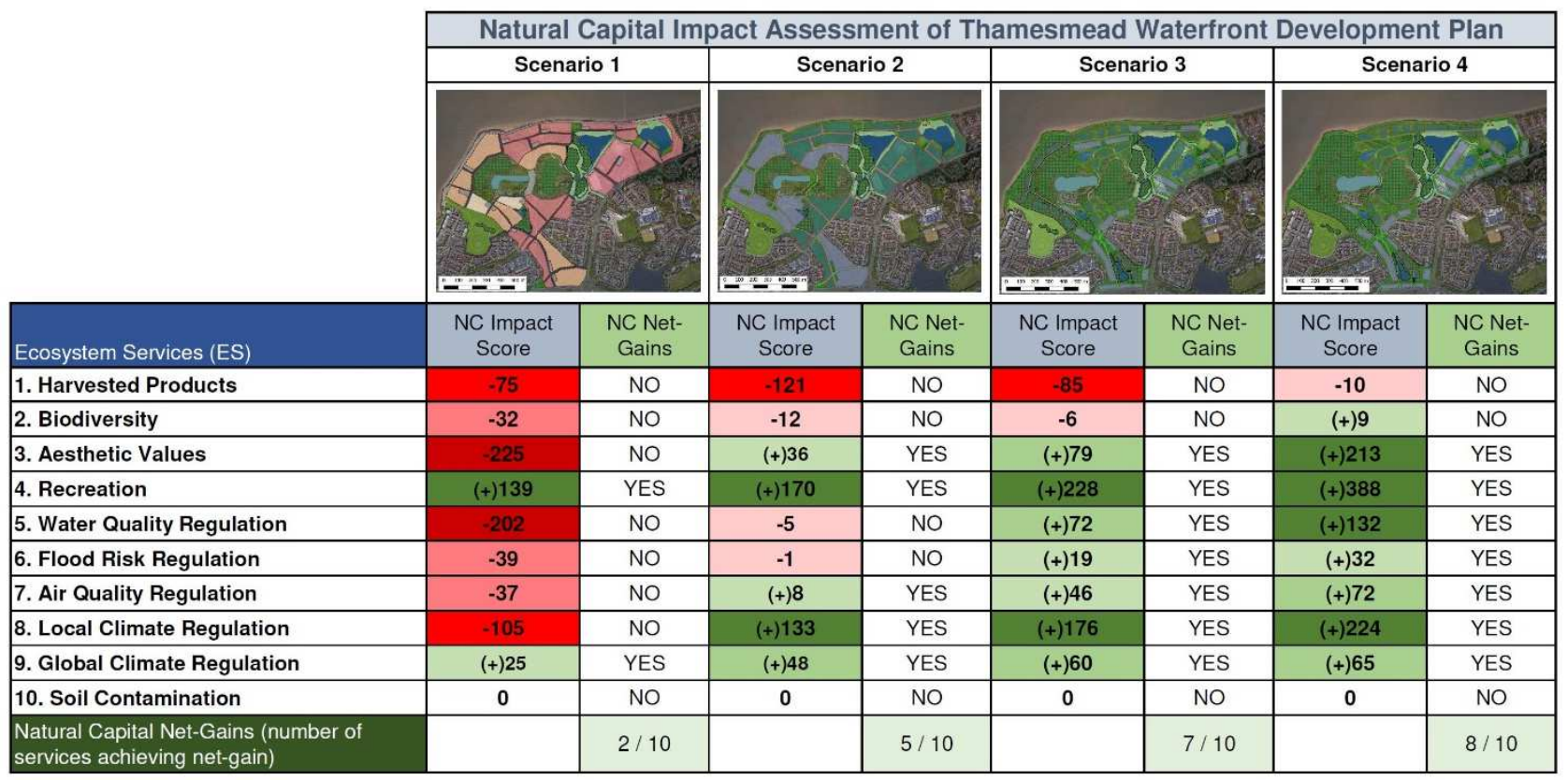

As seen in the first column of Table 2, the Scenario 1 results in only two positive ES, which are recreation $(+139)$ and global climate regulation $(+25)$. The positive recreation score is easily explained because the current land is not accessible to the public and as soon as new green space is open, it directly provides new leisure and outdoor activity space to citizens. All the other scores are negative, and the aesthetic values in particular (-225), which can be explained due to the traditional way of building and lots of grey infrastructure systems, such as roads and paved areas. Regarding Scenario 2, Table 2 reveals that five ES achieve UNC net-gain, which indicates a significant improvement compared to Scenario 1. However, there are still some important UES in negative values, e.g. harvested products (-121) or water quality regulation (-5); which means that built-up areas are predominant and more BGI is still needed. 
In Scenario 3 most UES are positive and achieve NC net-gains, but still harvested products (85) and biodiversity (-6) are negative. Having no harvested activity in the post-development design should not mean a decline in harvested products because no agriculture activities are present in the pre-development site either. This is interpreted as another limitation of the NCPT. In addition, biodiversity is negative because the tool sees "gardens" as a decline compared to the current "poor grassland", but the tool does not include any other land use options that could increase the sustainability score. In contrast, Recreation $(+228)$ is still the biggest positive score. This is explained firstly because the space is currently inaccessible and, secondly because there is a considerable increase in blue and green space as part of this urban design. Finally, in Scenario 4, we see all UES scoring positive values, with the exception of harvested products $(-10)$, for same reasons as in Scenario 3. All the other scores are soundly positive, which means that preserving the natural environment and creating a compact distribution with large amount of BGI around the buildings will be the most sustainable option to select.

The results collected in Table 2 provide a general idea of the TMWDP level of sustainability based on different design approaches; however, the scores are only an indication of the UES net-gain and the tool presents a large number of limitations. New land uses and new sustainable building typologies should be added as part of a new tool, e.g. 'buildings with rainwater harvesting', 'swales' or 'intensive' vs. 'extensive' green roofs. This demonstrates the necessity to create a new integrated modelling tool that improves these limitations and enables a more streamlined planning and development process, leading to a better quality and design for new urban developments.

\section{Discussion}

Prior work has documented different methods for urban sustainability assessment, trying to achieve an easy-to-use sustainability evaluation formula at the urban development scale and enabling urban stakeholders' collaboration (Joustra and Yeh, 2014; Mellino et al., 2014; Raymond et al., 2017; Ford et al., 2019; Tan et al., 2020). However, these studies have either 
been unsuccessful in recognising an applicable method to the UK planning system or have not been focused on the undeniable urban system's complexity. In this study, a new theoretical framework that combines urban design solutions with a series of evaluation metrics applied to the UK's urban planning system has been presented. The UPSUF aligns design solutions with the actions occurring at the decision-making and governance level. It aims to facilitate urban stakeholder partnership at these two levels (design and decision-making) and to generate factual impact at the early stages of the urban design with participatory engagement.

This engagement will be achieved by sharing activities, such as urban stakeholder or community group workshops. Collaborative workshops and social engagement events are proved to be very effective in raising general public awareness and government support towards sustainable architecture and new urban design solutions (see Puchol-Salort et al., 2018; Bell and Johnson, 2020).

Facing future work and aiming to increase the usability of UPSUF, one of the potential directions of this work will be to add approved certifications into the integrated evaluation toolkit. However, these certifications sometimes present a series of limitations and need a comprehensive revision (see Kaur and Garg, 2019). There are already some sources in the literature that looked for a revised method, with the Comprehensive Assessment Method for Sustainable Urban Development (CAMSUD; Ali-Toudert et al., 2020) being one of the most attractive ones. CAMSUD reports a detailed study for five of the most widely-used urban rating systems around the world, comparing their weaknesses and strengths. There are forty urban sustainability criteria presented in CAMSUD based on these well-established rating systems and UPSUF's goal will be to include these criteria in its integrated evaluation toolkit and examine to what extent the designed urban development project achieves each criterion.

UPSUF's functionality has considerable potential in systems modelling. Although for now it only includes a static evaluation of the urban development project based on a 'before-after' evaluation, new models that include a more dynamic approach should be considered in the next stages of the work. These novel models should have the capacity to link with: a) dynamic population trends; b) Life Cycle Assessment (LCA) methods applied to the urban scale in 
spatial planning (Bidstrup et al., 2015; Mirabella et al., 2018); c) Blue Green Infrastructure (BGI) cost-benefit analysis in the long term of the urban development; and, d) water infrastructure tools, such as CityWat (Dobson and Mijic, 2020). The exploration of new urban models will be part of the improved integrated evaluation toolkit of UPSUF.

Finally, new UPSUF's models will provide evidence of urban sustainability to urban stakeholders and decision-makers in the UK's planning context. Decision-makers have a huge responsibility to incentivise private developers towards more investment on urban development projects that combine private and public value. As Bateman and Mace (2020) suggest, public decision-makers can either create positive incentives, such as subsides or PES (Payment Ecosystem Services) schemes or, negative disincentives, such as taxes or deterrent regulations. Hence, the UPSUF will provide a new insight towards these incentives and help policy-makers to change the existing obsolete urban policies.

\section{Conclusion and future outlook}

In this paper a new framework for sustainability evaluation in the UK's urban planning context has been defined. The Urban Planning Sustainability Framework (UPSUF) is currently at the proof-of-concept stage and it will be further developed and improved during the next stages of this work. UPSUF's application shows potential for better urban planning decisions and therefore for essential benefits to the society.

Findings from this research applied to Thamesmead Waterfront Development Plan (TMWDP) indicated that a more compact building distribution with larger areas of Blue Green Infrastructure (BGI) will increase the level of Urban Ecosystem Services (UES) provided, these being understood as the number of benefits that citizens obtain from the natural environment and also representing a good measure for urban sustainability. Conventional design solutions, however, are in alignment with the traditional urban planning standards, which generally provide sprawl urbanisation with extensive impervious concrete-based infrastructure areas. One of the key factors for housing developers are the profitability opportunities of the urban development, not considering the long-term environmental performance of the project. Thus, 
there are research opportunities to expand the evaluation criteria of UPSUF and make it more dynamic, showing the cost-benefit analysis of the development, both to developers and Local Planning Authorities (LPAs). In these new scenarios, other variables such as future maintenance and long-term benefits to businesses and society of the BGI and the water infrastructure systems will be included (see Winch et al., 2020).

This work is focused on a particular urban development project (TMWDP) where the UNC value is higher than the average in other similar urban areas. This points to important directions for future research, such as including new case studies facing different challenges. These future studies will allow more robust data analysis as well as diverse and more collaborative research with different types of stakeholders. Additional societal and economic uncertainties, such as the Covid-19 pandemic and the consequences of the lockdown, will be also included in future urban scenarios simulations. Ultimately, this works supports the urban sustainability field's advancement towards a more integrated and multifaceted methodology, where built and ecological systems are widely seen as an interconnected entity.

\section{Acknowledgments}

This work would not have been possible without funding from the Engineering and Physical Sciences Research Council (EPSRC) Centre for Doctoral Training (CDT) in Sustainable Civil Engineering. The research reported in this paper was taken as part of the CAMELLIA project (Community Water Management for a Liveable London), funded by the Natural Environment Research Council (NERC) under grant NE/S003495/1. 


\section{Appendix A}

Table A.1: Blue Green urban design solutions used in the UPSUF, divided in three areas of study: i) BGI (Blue Green Infrastructure), ii) Urban form and, iii) Construction. Comparison of sustainable design solutions against traditional (grey) solutions.

\begin{tabular}{|c|c|c|}
\hline \multicolumn{3}{|c|}{ BLUE GREEN URBAN DESIGN SOLUTIONS IN UPSUF } \\
\hline Area & Sustainable Design Solutions & Traditional Solutions \\
\hline \multirow{9}{*}{ 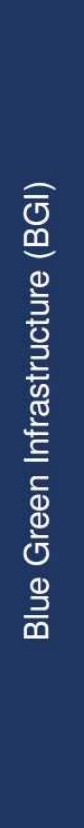 } & Street trees & Sterile corridors with hard and non-permeable roads/pavements \\
\hline & Permeable paving & Non-permeable paving \\
\hline & $\begin{array}{l}\text { Engineered stormwater controls (bioswales, rain } \\
\text { gardens and retention ponds) }\end{array}$ & Non-permeable surfaces directly connected to sewage system \\
\hline & (Blue) Green roofs & Hard surface roofs \\
\hline & Green façades/walls & Hard surface walls \\
\hline & Parks and open spaces & Non-shaded and non-permeable comunal spaces \\
\hline & Rainwater harvesting systems & $\begin{array}{l}\text { Large impermeable surfaces directly connected to sewage } \\
\text { systems }\end{array}$ \\
\hline & Ponds, waterways and wetlands & $\begin{array}{l}\text { Heavy underground water infrastructure disallowing water for } \\
\text { placemaking }\end{array}$ \\
\hline & Urban gardens & Large impermeable surfaces with no vegetation \\
\hline \multirow{4}{*}{ 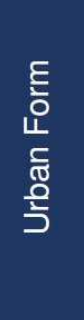 } & Building dimensions and spacing (compactness) & Too compact or too sprawl urbanisation \\
\hline & Building density and use & $\begin{array}{c}\text { Single use development (instead of mixed use) and lots of } \\
\text { dwellings/habitants per } \mathrm{m}^{2} \text { built }\end{array}$ \\
\hline & Surface properties (cover) & Impervious and artificial surfaces (horizontal and vertical) \\
\hline & Amount of green space around buildings & $\begin{array}{l}\text { No green around buildings, with mostly impervious and paved } \\
\text { areas }\end{array}$ \\
\hline \multirow{2}{*}{$\begin{array}{l}\text { 듬 } \\
\text { 을 } \\
\text { 는 } \\
\text { 등 }\end{array}$} & Use of sustainable materials (fabric) & Non-local and non-natural materials \\
\hline & $\begin{array}{l}\text { Efficient use of resources during construction and life- } \\
\text { time of the building (water, energy, etc.) }\end{array}$ & $\begin{array}{l}\text { Waste of water and energy during construction and building life- } \\
\text { time (low efficiency) }\end{array}$ \\
\hline
\end{tabular}


Table A.2: Comparison of the most widely assessed UES based on two acknowledged sources of literature. UES in green are those identified in both sources, while those in orange are only identified in one of the sources, but considered critical for the UPSUF's aim. There are also some UES in white that are not included in this study and some extra comments that justify this selection (ticks are UES found in both sources without any comments, and crosses are UES that has not been selected). Last column presents the ten UES included and studied by UPSUF (Urban Planning Sustainability Framework).

\begin{tabular}{|c|c|c|}
\hline \multicolumn{3}{|c|}{ URBAN ECOSYSTEM SERVICES (UES) COMPARISON } \\
\hline \begin{tabular}{|c|} 
Most common UES (based on \\
Keeler et al. 2019) \\
\end{tabular} & $\begin{array}{l}\text { NBS-related ES (based on } \\
\text { Bozovic et al. 2017) }\end{array}$ & Comments \\
\hline Urban air quality & Air quality & $\checkmark$ \\
\hline Carbon sequestration & & $x$ \\
\hline Coastal protection & & $x$ \\
\hline UHI and heat extremes mitigation & UHI mitigation & $\checkmark$ \\
\hline & Water quality & $\begin{array}{l}\text { Water quality is important for urban environments } \\
\text { (both in landscapes and buildings) }\end{array}$ \\
\hline Urban water supply & & $\begin{array}{l}\text { An important UES to be considered when } \\
\text { designing buildings and public spaces }\end{array}$ \\
\hline $\begin{array}{c}\text { Stormwater and wastewater } \\
\text { management }\end{array}$ & \multirow{2}{*}{ Flood mitigation } & $\begin{array}{c}\text { Water management can be included with flood } \\
\text { mitigation }\end{array}$ \\
\hline Riverine flood impact reduction & & $\checkmark$ \\
\hline Recreation opportunities & \multirow{2}{*}{ Well-being } & \multirow{2}{*}{$\begin{array}{l}\text { Well-being' might include 'recreation' and 'mental } \\
\text { health' }\end{array}$} \\
\hline Mental Health & & \\
\hline \multirow[t]{5}{*}{ Urban agriculture } & & Very important UES in an urban context \\
\hline & Biodiversity & Very important for nature conservation \\
\hline & Aesthetics & $\begin{array}{c}\text { Very important when designing an urban } \\
\text { development project }\end{array}$ \\
\hline & Noise reduction & $x$ \\
\hline & Resources efficiency & Very important UES for energy consumption \\
\hline 10 & 9 & \\
\hline
\end{tabular}

\begin{tabular}{|c|}
\hline UPSUF UES \\
\hline Urban Air quality \\
\hline \\
\hline UHI mitigation \\
\hline Urban Water quality \\
\hline Urban water supply \\
\hline $\begin{array}{c}\text { Flood mitigation and } \\
\text { stormwater management }\end{array}$ \\
\hline Recreation and well-being \\
\hline Urban agriculture \\
\hline Biodiversity \\
\hline Aesthetics \\
\hline \\
\hline Resources efficiency \\
\hline 10 \\
\hline
\end{tabular}




\section{References}

Ahmadian, E., et al. (2019). Sustainable cities: The relationships between urban built forms and density indicators. Cities: 95.

Ali-Toudert, F., et al. (2020). Comprehensive Assessment Method for Sustainable Urban Development (CAMSUD) - A New Multi-Criteria System for Planning, Evaluation and Decision-Making. Progress in Planning 140: 100430.

Askew, P. (2018) Creating Value for People in Thamesmead - Well-being and Green Infrastructur. Conference presentation. Valuing Landscape Conference 2018, London.

Barbier, E. B. (2019). The concept of natural capital. Oxford Review of Economic Policy 35(1): $14-36$.

Bateman, I. J. and G. M. Mace (2020). The natural capital framework for sustainably efficient and equitable decision making. Nature Sustainability.

Batty, M. (2008). The Size, Scale, and Shape of Cities. Science 319: 769-771.

Bell, S. and Johnson, C. (2020). Kipling Rooftop Garden: scaling water impacts for urban sustainability. Anthropology and Geography: Dialogues Past, Present and Future Conference Paper. Royal Anthropological Institute.

Bide, P. and Coleman, A. (2019). Delivering better water management through the planning system. C787A-B-C-E, Ciria, London. ISBN: 978-0-86017-892-7 
Bidstrup, M., et al. (2015). Life Cycle Assessment in spatial planning - A procedure for addressing systemic impacts. Cleaner Production 91: 136-144.

Boeing, G. (2018). Measuring the complexity of urban form and design. URBAN DESIGN International 23(4): 281-292.

Bozovic, R.; Maksimovic, C.; Mijic, A.; Suter, I; Van Reeuwijk, M. (2017). Blue Green Solutions. A Systems Approach to Sustainable, Resilient and Cost-Efficient Urban Development. Imperial College London

BRE Global (2017) BREEAM Communities Technical Manual. SD202-1.2:2012. Code for a Sustainable Built Environment. Retrieved from: https://www.breeam.com/communitiesmanual

Bright, G., et al. (2019). Measuring natural capital: towards accounts for the UK and a basis for improved decision-making. Oxford Review of Economic Policy 35(1): 88-108.

Brundtland, G. H. (1987). Our common future/Brundtland report. United Nations World Commission on Environment and Development.

Carmona, M., Heath, T., Tiesdell, S., \& Oc, T. (2010). Public places, urban spaces: the dimensions of urban design. Routledge, 2nd Edition.

Cavender-Bares, J., et al. (2015). A sustainability framework for assessing trade-offs in ecosystem services. Ecology and Society 20(1).

Cherry, B. and Pevsner, N. (1964). The buildings of England: London. 2: South. Harmondsworth. Penguin Books. 
Clark, J., et al. (Policy Connect) (2018). Bricks \& Water: A Plan of Action for Building Homes and Managing Water in England. Westminster Sustainable Business Forum. Retrieved from: https://www.policyconnect.org.uk/research/bricks-water-plan-action-building-homes-andmanaging-water-england

Clark, J., et al. (Policy Connect) (2019). How can sustainable drainage (SuDS) improve our environment? Westminster Sustainable Business Forum. Discussion summary.

Committee on Climate Change (2019). UK Housing: Fit for the Future? Public Report. Retrieved from: https://www.theccc.org.uk/publications/

Davoudi, S. and Sturzaker, J. (2017). Urban form, policy packaging and sustainable urban metabolism. Resources, Conservation and Recycling 120: 55-64.

Dickie, I. and Neupauer, S. (2019). Natural capital accounts: nations and organizations. Journal of Environmental Economics and Policy 8(4): 379-393.

Dobson, B. and Mijic, A. (2020). Protecting rivers by integrating supply-wastewater infrastructure planning and coordinating operational decisions. Environmental Research Letters.

Edenhofer, O., et al. (2014) IPCC, 2014: Climate Change 2014: Mitigation of Climate Change. Contribution of Working Group III to the Fifth Assessment Report of the Intergovernmental Panel on Climate Change. Cambridge University Press, Cambridge, United Kingdom and New York, NY, USA.

Environmental Agency (2009). Water for People and the Environment. Water Resources Strategy Regional Action Plan for Southern Region. Public Report. 
Erell, E. P., Pearlmutter, D., \& Williamson, T. (2015). Urban microclimate: designing the spaces between buildings. New York, Taylor \& Francis. ISBN: 978-1-84407-467-9.

Greater London Authority (GLA), (2018). London Environment Strategy. City Hall. London. Retrieved from: https://www.london.gov.uk/what-we-do/environment/london-environmentstrategy

Greater London Authority (GLA), (2018). Mayor's Transport Strategy. Mayor of London. City Hall. London. Retrieved from: https://www.london.gov.uk/what-we-do/transport/our-visiontransport/mayors-transport-strategy-2018?intcmp $=46686$

Greater London Authority (GLA), (2019). The Draft London Plan. Consolidated changes version - Clean July 2019. Retrieved from: https://www.london.gov.uk/what-wedo/planning/london-plan/new-london-plan/draft-london-plan-consolidated-suggestedchanges-version-july-2019

Fang, K., et al. (2018). Sustainability of the use of natural capital in a city: Measuring the size and depth of urban ecological and water footprints. Science of The Total Environment 631632: 476-484.

Ford, P. and Baikie, K. (2016). Thamesmead: kickstarting the transformation of a stalled new town. Town and Country Planning, 85(1), pp. 41-44.

Ford, A., et al. (2018). Land-use transport models for climate change mitigation and adaptation planning. Journal of Transport and Land Use 11(1). 
Ford, A., et al. (2019). A multi-scale urban integrated assessment framework for climate change studies: A flooding application. Computers, Environment and Urban Systems 75: 229_ 243.

HM Government, Department for Communities and Local Government (2015). Plain English Guide to the Planning System. Retrieved from:

https://www.gov.uk/government/publications/plain-english-guide-to-the-planning-system

HM Government (2018). A green future: our 25 year plan to improve the environment. Public report of United Kingdom. Retrieved from: www.gov.uk/government/publications

HM Government, Ministry of Housing, Communities and Local Government (2019). National Planning Policy Framework. Revised version, London. ISBN: 978-1-5286-1033-9

Hölzinger, O., et al. (2019). NCPT - Managing Environmental Gains and Losses. Town \& Country Planning 88(5):166-170. Mainstreaming Green Infrastructure in the Planning System.

Horton, B., Digman, C.J., Ashley, R.M. and McMullan, J. (2019). Guidance to assess the benefits of blue and green infrastructure using B£ST. Ciria. Release version 5. ISBN: 0-86017934-6 (10).

IBEC (Institute for Building Environment and Energy Conservation) (2014). CASBEE for Urban Development Technical Manual. $1^{\text {st }}$ Edition. Japan Sustainable Biuilding Consortium (JSBC). Retrieved from: http://www.ibec.or.jp/CASBEE/english/download/

Jabareen, Y. R. (2006). Sustainable Urban Forms : Their Typologies, Models, and Concepts. Journal of Planning Education and Research 26(1): 38-52. 
Joustra, C. M. and Yeh, D. H. (2014). Framework for net-zero and net-positive building water cycle management. Building Research \& Information 43(1): 121-132.

Kabisch, N., et al. (2017). Nature-based Solutions to Climate Change Adaptation in Urban Areas. Linkages between Science, Policy and Practice. Springer Open. ISBN: 9783319537504

Kapetas, L. and Fenner, R. (2020). Integrating blue-green and grey infrastructure through an adaptation pathways approach to surface water flooding. Philosofical Transactions Royal Society A 378(2168): 20190204.

Kaur, H. and Garg, P. (2019). Urban sustainability assessment tools: A review. Cleaner Production 210: 146-158.

Keeler, B. L., et al. (2019). Social-ecological and technological factors moderate the value of urban nature. Review Article. Nature Sustainability 2(1): 29-38.

Keating, C., et al. (2003). System of Systems Engineering. Engineering Management Journal 15(3): 36-45.

Kilbert, Charles J. (2013). Sustainable Construction: Green Building Design and Delivery. 3rd Ed., New Jersey, John Wiley \& Sons. ISBN: 978-0-470-90445-9

Kotov, V. (1999). Systems of Systems as Communicating Structures. Object-Oriented Technology and Computing Systems Re-engineering. H. Zedan and A. Cau, Woodhead Publishing: 141-154. 
Little, J. C., et al. (2019). A tiered, system-of-systems modeling framework for resolving complex socio-environmental policy issues. Environmental Modelling \& Software 112: 82-94.

Mace, G. M., et al. (2011). UK National Ecosystem Assessment: Chapter 2: Conceptual Framework and Methodolog. Public report.

Mace, G. M., et al. (2015). Towards a risk register for natural capital. Review article. Journal of Applied Ecology 2015, 52, 641-653.

McPhearson, T., et al. (2016). Advancing understanding of the complex nature of urban systems. Ecological Indicators 70: 566-573.

Mellino, S., et al. (2014). An emergy-GIS approach to the evaluation of renewable resource flows: A case study of Campania Region, Italy. Ecological Modelling 271: 103-112.

Mijic, A. and Brown, K. (2019). Integrating Green and Blue Spaces Into Our Cities: Making It Happen. Grantham Institute Briefing Paper, No 30. Imperial College London.

Mirabella, N., et al. (2018). Current trends and limitations of life cycle assessment applied to the urban scale: critical analysis and review of selected literature. The International Journal of Life Cycle Assessment 24(7): 1174-1193.

Nesshöver, C., et al. (2017). The science, policy and practice of nature-based solutions: An interdisciplinary perspective. Science of The Total Environment 579: 1215-1227.

Newton, P.W. and Rogers, B.C. (2020). Transforming Built Environments: Towards Carbon Neutral and Blue-Green Cities. Sustainability 12, 4745. 
Oke, T. and Stewart, I. D. (2012). Local Climate Zones for Urban Temperature Studies. Bulletin of the American Meteorological Society 93(12): 1879-1900.

Oke, T., Mills, G., Christen, A., \& Voogt, J. (2017). Urban Climates. Cambridge, Cambridge University Pres. ISBN: 9781107429536

Opoku, A. (2019). Biodiversity and the built environment: Implications for the Sustainable Development Goals (SDGs). Resources, Conservation and Recycling 141: 1-7.

Pandit, A., et al. (2017) Infrastructure Ecology: An Evolving Paradigm for Sustainable Urban Development. Cleaner Production 163: S19-S27.

Passive House Institute (2020). Building Certification Guide. $3^{\text {rd }}$ Editidion, Darmstadt. Retrieved from: https://passiv.de/downloads/03_building_certification_guide.pdf

Puchol-Salort, P. and Schiano-Phan, R. (2018). Sustainable Architecture and Social Engagement for Flooding and Drought Resilience. PLEA 2018 Conference Paper, Smart and Healthy within the 2-degree Limit.

Raymond, C. M., et al. (2017). A framework for assessing and implementing the co-benefits of nature-based solutions in urban areas. Environmental Science \& Policy 77: 15-24.

Riera Pérez, M. G., et al. (2018). Fostering sustainable urban renewal at the neighborhood scale with a spatial decision support system. Sustainable Cities and Society 38: 440-451.

Royal Borough of Greenwich (2014). Royal Greenwich Local Plan: Core Strategy with Detailed Policies. London. Retrieved from: https://www.royalgreenwich.gov.uk/planningcorestrategy 
Russo A., Cirella G.T. (2020). Urban Sustainability: Integrating Ecology in City Design and Planning. In: Cirella G. (eds) Sustainable Human-Nature Relations. Advances in 21st Century Human Settlements. Springer, Singapore.

Shao, Z., et al. (2020). Urban sprawl and its impact on sustainable urban development: a combination of remote sensing and social media data. Geo-spatial Information Science: 1-15.

Tan, P. Y., et al. (2020). A conceptual framework to untangle the concept of urban ecosystem services. Landscape and Urban Planning 200: 103837.

UK Natural Capital Committee (UKNCC) (2017). Economic Valuation and its application in natural capital management and the Government's 25 Year Environmental Plan.

United Nations (2014). World urbanization prospects: The 2014 revision, highlights. Population division. United Nations.

UNISDR (United Nations Office for Disaster Reduction) (2017). How to Make Cities More Resilient. A Handbook For Local Government Leaders. Geneva, $1^{\text {st }}$ Edition. Retrieved from: https://www.undrr.org/publication/how-make-cities-more-resilient-handbook-localgovernment-leaders-0

USGBC (2012). LEED Certification Policy Manual. For Use With All LEED Rating Systems. Retrieved from: https://www.usgbc.org/resources/leed-certification-policy-manual

Vivid Economics (2018). 30-Year Green Infrastructure Strategy for Thamesmead. Commissioned by Peabody and Landscape and Green Infrastructure Strategy for Thamesmead. 
Whyte, J., et al. (2020). A Research Agenda on Systems Approaches to Infrastructure. Civil Engineering and Environmental Systems.

Williams, A., et al. (2017). Systems thinking: A review of sustainability management research. Cleaner Production 148: 866-881.

Winch, R., et al. (2020). Nature-based solutions to the climate emergency. The benefits to business and society. IGNITION Project public report. Retrieved from: https://www.ukgbc.org/ukgbc-work/nature-based-solutions-to-the-climate-emergency-thebenefits-to-business-and-society/

Wu, S., et al. (2019). Relationships between urban development level and urban vegetation states: A global perspective. Urban Forestry \& Urban Greening 38: 215-222.

Yang, W., et al. (2016). Urban water sustainability framework and application. Ecology and Society $21(4)$.

Yeo, In-Ae and Lee, Eunok (2018). Quantitative study on environment and energy information for land use planning scenarios in eco-city planning stage. Applied Energy 230: 889-911. 